\title{
Population structure and fecundity of the microcopepod Oncaea bispinosa in the Red Sea-a challenge to general concepts for the scaling of fecundity
}

\author{
Ruth Böttger-Schnack ${ }^{1, *}$, Dietrich Schnack ${ }^{2}$ \\ ${ }^{1}$ Moorsehdener Weg 8, 24211 Rastorf-Rosenfeld, Germany \\ ${ }^{2}$ Leibniz-Institut für Meereswissenschaften, Düsternbrooker Weg 20, 24105 Kiel, Germany
}

\begin{abstract}
General concepts of reproductive traits in pelagic marine copepods have been developed largely without data from the microcopepod family Oncaeidae. For a very abundant oncaeid species in the Red Sea, Oncaea bispinosa Böttger-Schnack, reproductive parameters are provided and used for testing how the copepod family Oncaeidae may fit into these concepts. Total number and vertical distribution of eggs of this species have been calculated for populations in the northernmost Red Sea and the Gulf of Aqaba during spring, based on counts of detached egg sacs retained in fine mesh net samples. Reproduction is indicated to take place in the meso- and bathypelagic zones, with maximum abundances of eggs occurring within the deep population centres of females at 250 to $450 \mathrm{~m}$ depth. The epipelagic population appeared to be non-reproductive. By calculating the biomass of the eggs and the females using published data on size/weight relationships, a first estimate of the reproductive potential of $O$. bispinosa was obtained and compared with various other oncaeid species. The presently available data for Oncaeidae in total suggest a relationship between single egg $\left(E_{\mathrm{c}}\right)$ and female $\left(F_{\mathrm{c}}\right)$ carbon weight $\left(E_{\mathrm{c}}=0.012 \times F_{\mathrm{c}}{ }^{0.48}\right)$ that differs from corresponding regressions reported in the literature for other marine pelagic copepods. In addition, regressions are given for minimum and maximum clutch carbon related to female carbon weight. Potential egg production rates of $O$. bispinosa have been calculated from the observed fractions of egg-bearing females and published data on egg developmental times, as available for larger oncaeids. These production rates appear to be lower than have been observed in experimental studies for different pelagic microcopepod taxa. Remaining uncertainties in generalizing concepts for the scaling of fecundity in pelagic marine copepods are discussed, and the need for more comparable data, especially for the numerically abundant oncaeids, is emphasized.
\end{abstract}

KEY WORDS: Oncaeidae $\cdot$ Fecundity $\cdot$ Vertical distribution $\cdot$ Mesopelagic zone $\cdot$ Red Sea

\section{INTRODUCTION}

Oncaeid microcopepods are important members of oceanic plankton communities ranging from low to high latitudes (e.g. Judkins 1980, Hopkins 1985, Roman et al. 1985, Böttger 1987, Richter 1994) and from epi- to bathypelagic depth zones (e.g. Boxshall 1977, Wishner 1979, Paffenhöfer 1983, Böttger-Schnack 1994, Yamaguchi et al. 2002). Although their high numerical abundance and species diversity have been increasingly recognized (e.g. Heron 1977, Böttger-
Schnack 1994, 1999, Heron \& Bradford-Grieve 1995, Kršinić 1998, Hopcroft et al. 2001, Nishibe \& Ikeda 2004, Satapoomin et al. 2004), our present knowledge on the ecology of oncaeid copepods is still rather limited (Böttger-Schnack et al. 1989, Paffenhöfer 1993). In particular, little information on the population dynamics and life strategies of species is available for oncaeids. As a consequence, global syntheses on marine planktonic copepod production and mortality estimates (e.g. Huntley \& Lopez 1992, Kiørboe \& Sabatini 1995, Hirst \& Kiørboe 2002, Bunker \& Hirst 
2004) are still incomplete because information on this important non-calanoid taxon is lacking.

The few available data on reproduction parameters of oncaeid copepods mostly refer to larger species between 0.9 and $\sim 1.4 \mathrm{~mm}$ female body length. Kovalev (1970) reported on the total egg numbers of Oncaea mediterranea, $O$. conifera, O. media and $O$. minuta from the Mediterranean by counting the number of eggs from field-collected ovigerous females and found a linear relationship between female sizes and total egg numbers in both inter- and intraspecific comparisons. Sazhina (1985) calculated the egg production rate of $O$. venusta, $O$. conifera and $O$. media from the equatorial Indian Ocean based on observations of clutch sizes and egg developmental times obtained from ship board experiments with field-collected females. Hirakawa (1995) studied the effect of varying temperatures on the egg production of field-collected ovigerous females of $O$. venusta from Japanese waters in the laboratory and found an optimum temperature for maximum clutch sizes of between 20 and $27.5^{\circ} \mathrm{C}$. More recently, Satapoomin et al. (2004) calculated the egg production rate of $O$. venusta from the egg-hatching rate measured in the laboratory (number of hatched nauplii counted) and the in situ egg:female ratio of the field population (i.e. including loose egg sacs and females not carrying egg sacs) from fine mesh net samples along a transect from the shallow coastal area to deep oceanic waters in the Andaman Sea (Indian Ocean). For the warm-water cosmopolitan O. mediterranea, experimental results on reproduction rates and developmental times were obtained for specimens collected from the southeastern shelf of the USA (Paffenhöfer 1993) and from the tropical Atlantic off Jamaica (Webber \& Roff 1995). From the observation of a low egg production rate of $O$. mediterranea, which was compensated for by a higher female longevity, Paffenhöfer (1993) pointed out that the reproduction strategy of oncaeid copepods seems to be comparable to the cyclopoid Oithona plumifera studied simultaneously but may differ from that of similar-sized calanoids. This comparison, however, is based on observations of a single large epipelagic oncaeid species and may not be applicable to oncaeid copepods in general. The numerous smaller oncaeid species in the size range between 0.2 and $0.8 \mathrm{~mm}$ (adult stages), which appear to differ in their reproduction strategy from larger species of the family (see below), have not yet been considered for such a comparison. The scarce information on smaller oncaeids includes results from Metz (1996), who studied the reproduction of $O$. curvata (body length $=0.7 \mathrm{~mm}$ ) in the Weddell Sea, Antarctica, calculated from the frequency of ovigerous females and their egg numbers (clutch size) from the attached egg sacs in the entire water column during 2 seasons.
Oncaeid copepods are egg-carrying spawners which usually have paired dorsal eggs sacs. The only exception known so far is Monothula subtilis (Giesbrecht), which carries an unpaired dorsal egg sac (BöttgerSchnack \& Huys 2001). Larger species of Oncaeidae (between 0.9 and $1.4 \mathrm{~mm}$ female body length) have been found to carry a great number (up to 60) of relatively small eggs per sac (e.g. Kovalev 1970, Sazhina 1985, Paffenhöfer 1993, Hirakawa 1995), while for small species of less than $0.5 \mathrm{~mm}$ female body length a very low number of relatively large eggs has been reported (Böttger-Schnack et al. 1989). From the observed size-specific difference in clutch size, but not in egg size, a size-dependent difference in the reproduction strategies among oncaeid species was hypothesized by Böttger-Schnack et al. (1989). However, the limited data set was not sufficient for any more general conclusions, as information on egg sizes and/or numbers was not available for the majority of the ca. 80 oncaeid species known at that time. One reason for this insufficient knowledge is the methodical problems of collecting ovigerous females: the egg sacs easily become detached from the females during collection and handling and are thus lost through the mesh openings due to their small size and/or cannot subsequently be identified from the entire plankton samples. Moreover, the difficulties in species identification of oncaeids may have hampered the recognition of species-specific differences in egg sizes and numbers, as the family includes many sibling species described only recently, such as the conifera-group (over 10 species, Heron \& Bradford-Grieve 1995, Heron \& Frost 2000) or the media-group (over 3 species, Böttger-Schnack 2001). Thus, the earlier reproduction parameters reported under these names (e.g. Kovalev 1970, Sazhina 1985) possibly refer to species groups.

Oncaea bispinosa, a small oncaeid of ca. $0.3 \mathrm{~mm}$ body length, is a dominant microcopepod species in the Red Sea, with adults accounting for up to $20 \%$ of the total copepod numbers (excluding nauplii) in the lower epipelagic and upper mesopelagic zones (Böttger-Schnack 1990a,b, 1995 as O. zernovi). The taxonomy and zoogeography of the species, which represents a sister taxon of $O$. zernovi Shmeleva, has been described by Böttger-Schnack (2002). Zernovi-type oncaeids have recently been found to be among the most numerous microcopepod species in low latitudes, including the Atlantic, Pacific and Indian Oceans, where they occur over extended vertical depth ranges from the (sub)surface to more than $1000 \mathrm{~m}$ (see Böttger-Schnack 2002 for references). During a recent study on the vertical distribution and community structure of the microcopepod fauna in the Gulf of Aqaba and the northern Red Sea (cf. Böttger-Schnack et al. 2001), ovigerous females of $O$. bispinosa were re- 
corded for the first time. The small mesh net samples also yielded high numbers of the typical egg sacs of the species, which had become detached from the females during handling and/or preservation processes. The present paper reports on the abundance and vertical distribution of egg sacs, total egg numbers and adult and late juvenile copepodid stages of $O$. bispinosa in the entire water column down to a maximum depth of $800 \mathrm{~m}$ in the northernmost Red Sea and the Gulf of Aqaba during spring. By calculating the biomass of the eggs and the females, using published data on size-weight relationships, a first estimate of the reproductive potential of $O$. bispinosa has been obtained and is compared with various other oncaeid species.

\section{MATERIALS AND METHODS}

Field data (plankton sampling). Zooplankton samples were collected during the RV 'Meteor' Cruise 44/2 on 1 to 6 March 1999 at 4 stations along a transect from the northernmost Red Sea to the Gulf of Aqaba (Fig. 1). A multiple opening-closing net (Weikert \& John 1981) with a mouth area of $0.25 \mathrm{~m}^{2}$ equipped with 5 nets of $0.055 \mathrm{~mm}$ mesh size was used to sample consecutivedepth strata at vertical hauls down to a maximum depth of $800 \mathrm{~m}$ (near-bottom). Samples were taken mostly at $50 \mathrm{~m}$ intervals between 0 and $450 \mathrm{~m}$ and at 50 to $150 \mathrm{~m}$ intervals between 450 and $800 \mathrm{~m}$. In the northern Gulf of Aqaba (Stn 151) sampling was limited to the upper $450 \mathrm{~m}$ of the water column, not including the deepest layer from $450 \mathrm{~m}$ to the bottom at $600 \mathrm{~m}$ depth. Plankton samples were initially fixed in a $4 \%$ formaldehyde-seawater solution buffered with borax. For sorting, the samples were transferred to a preservation fluid of $5 \%$ propylene glycol, $0.5 \%$ propylene phenoxetol and $94.5 \%$ filtered seawater (Steedman 1976) and retransferred to a $4 \%$ formaldehyde-seawater solution afterwards. In the laboratory, entire samples were scanned for ovigerous females, and those with spermatophores attached to the genital doublesomite as well as for mating pairs, in which the male clasps the female urosome with its maxillipeds (e.g. Böttger-Schnack 2001, her Fig. 21A).

For numerical analysis, samples were divided into 2 size fractions by filtration through $0.3 \mathrm{~mm}$ mesh gauze. Abundances of adult and late juveniles (>CIV-CV) of Oncaea bispinosa and the typical egg sacs of the species were counted in subsamples of the smaller size fraction containing a total of 300 to 500 oncaeids. The identification of late juvenile $\mathrm{O}$. bispinosa was based on their general habitus and body length. Due to some uncertainties in the identification at the beginning of the study, the actual abundances of late juveniles may have been underestimated at 2 of the 4 stations investigated (northern Red Sea and southernmost Gulf of Aqaba); smaller juveniles of the species were noted but could not be quantitatively separated from similar-sized species. Separation of $O$. bispinosa egg sacs from similar-sized egg sacs of other species was based on a combination of characteristics, including (1) egg sac form (length to width), (2) egg sizes, (3) egg numbers, (4) arrangement of eggs in the sac (1 layer, 2 rows) and (5) colour (transparency) of eggs. Quantitative analyses were made under a stereomicroscope at a magnification of 40 to $75 \times$. Taxonomic figures of the ovigerous female and the detached egg sacs were prepared using a camera lucida on a Leitz Dialux differential interference contrast microscope at a magnification of $400 \times$.

The proportion of ovigerous females was calculated from half the number of egg sacs divided by the number of females in the respective sample, assuming that (1) all egg sacs sampled in one depth layer got detached from females in the same layer and (2) all ovigerous females had carried 2 egg sacs. Environmental conditions during the sampling period were taken from a cruise report of RV 'Meteor' 44/2 (Pätzold

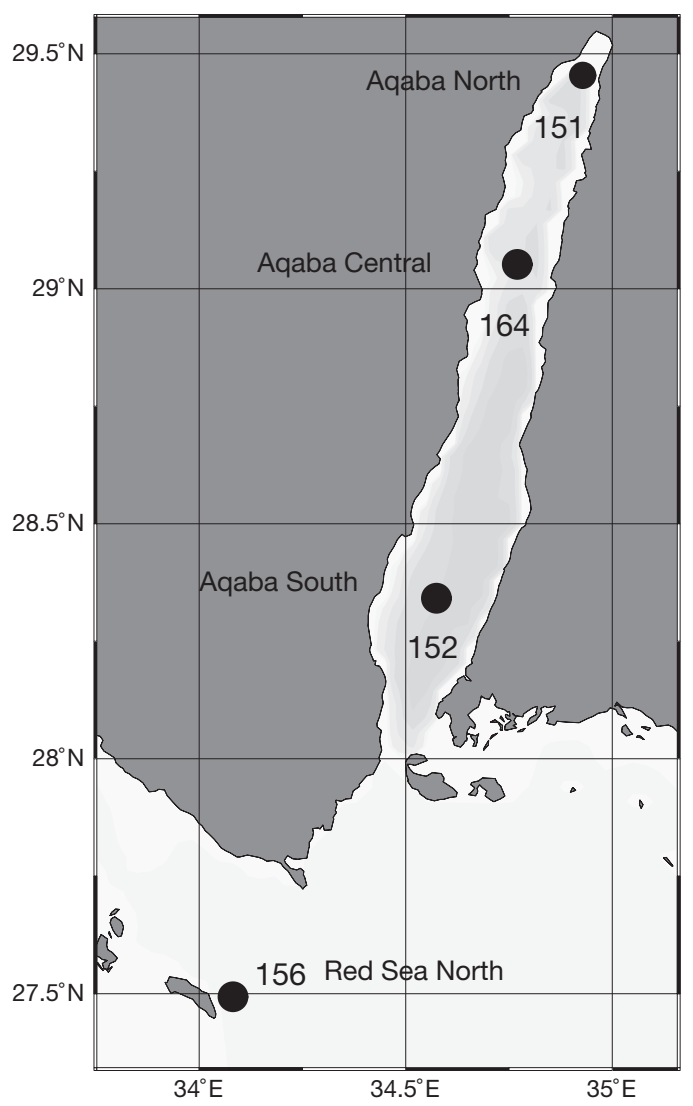

Fig. 1. Plankton sampling stations along a transect from the northernmost Red Sea to the Gulf of Aqaba during RV 'Meteor' Cruise 44/2, March-April 1999 
Table 1. Reproductive parameters of oncaeid species. Compilation of published and newly collected data on female size, egg size (diameter) and total egg numbers. Egg and female carbon weights calculated after Kiorbøe et al. (1985) and Satapoomin (1999) respectively. elong. = elongate; $\mathrm{cl} .=$ cluster; fem. $=$ female; RS = Red Sea; s.l. = sensu lato; s. str. = sensu stricto (for definition of Oncaea s. str. see Böttger-Schnack 2001). Source-1: Kovalev (1970); 2: Heron (1977); 3: Sazhina (1985); 4: Böttger-Schnack et al. (1989); 5: Paffenhöfer (1993); 6: Böttger-Schnack (1999); 7: Böttger-Schnack (2000); 8: Böttger-Schnack (2001); 9: BöttgerSchnack \& Huys (1997); 10: Böttger-Schnack \& Huys (2001); 11: Böttger-Schnack (2003); 12: This study; 13: Björnberg (1972); 14: Y. Nishibe (pers. comm.); 15: Metz (1996)

\begin{tabular}{|c|c|c|c|c|c|c|c|c|}
\hline Genus & Species & $\begin{array}{l}\text { Female } \\
\text { total } \\
\text { length } \\
(\mu \mathrm{m})\end{array}$ & $\begin{array}{l}\text { Female } \\
\text { prosome } \\
\text { length } \\
(\mu \mathrm{m})\end{array}$ & $\begin{array}{c}\text { Female } \\
\text { weight } \\
\text { carbon } \\
(\mu g)\end{array}$ & $\begin{array}{l}\text { No. of } \\
\text { egg sacs }\end{array}$ & $\begin{array}{l}\text { Type of } \\
\text { Form }\end{array}$ & $\begin{array}{l}\text { egg sac } \\
\text { No. of } \\
\text { layers/rows }\end{array}$ & $\begin{array}{l}\text { Clutch size } \\
\text { eggs per female }\end{array}$ \\
\hline Oncaea s.l. & vojanitskii-group & 240 & 159 & 0.061 & 2 & Single egg & - & 2 \\
\hline Oncaea s.l. & bispinosa & 330 & 223 & 0.162 & 2 & Oblong & $1 / 2$ & $10-16$ \\
\hline Spinoncaea & ivlevi+humesi & 340 & 197 & 0.113 & 2 & Irregular & $1 / 1$ & 4 \\
\hline Triconia & giesbrechti & 435 & 294 & 0.361 & 2 & Oval & $1-2 / 1-2$ & $10-12$ \\
\hline Oncaea s.l. & ovalis-group & 450 & 305 & 0.402 & 2 & Oblong & $1-2 / 1-2$ & 8 \\
\hline Epicalymma & sp. & 450 & 287 & 0.339 & 1 & Spherical & $1 / 2$ & 4 \\
\hline Triconia & dentipes & 470 & 311 & 0.425 & 2 & Oblong & $1-2 / 1-2$ & $8-16$ \\
\hline Triconia & elongata & 475 & 300 & 0.383 & 2 & Oblong & $1-2 / 1-2$ & 14 \\
\hline Monothula & subtilis & 490 & 309 & 0.418 & 1 & Oval-elong. cl. & $2 / 3$ & 16 \\
\hline \multirow{2}{*}{ Oncaea s. str. } & waldemari & 490 & 311 & 0.425 & 2 & Oval & $2-3 / 2-3$ & $20-24$ \\
\hline & & 555 & 351 & 0.604 & 2 & Oval & $2 / 2-3$ & $16-18$ \\
\hline \multirow[t]{3}{*}{ Oncaea s. str. } & scottodicarloi & 510 & 341 & 0.556 & 2 & Oval & & 12 \\
\hline & & 510 & 341 & 0.556 & 2 & Oval & $2 / 2-3$ & 15 \\
\hline & & 600 & 429 & 1.081 & 2 & Oval-oblong & & \\
\hline Triconia & minuta-group & $440-560$ & & & 2 & & & $10-22$ \\
\hline Triconia & minuta & 520 & 370 & 0.704 & 2 & Oval cl. & $2-3 / 3$ & $22-24$ \\
\hline Triconia & hawii & 530 & 371 & 0.710 & 2 & Oblong & $1 / 1$ & $4-6$ \\
\hline Triconia & umerus & 590 & 424 & 1.045 & 2 & Oval & & 30 \\
\hline Triconia & recta & 610 & 394 & 0.845 & 2 & Oval & $2 / 2$ & $16-20$ \\
\hline Oncaea s.l. & parila & 627 & 439 & 1.156 & 2 & Oval & 2 & $11-12$ \\
\hline Triconia & rufa & 640 & 405 & 0.915 & 2 & Oblong-oval & $1-2 / 1-2$ & 8 \\
\hline Oncaea s. str. & clevei+paraclevei & 640 & 405 & 0.915 & 2 & Oval & $2-3 / 2-3$ & $30-40$ \\
\hline Triconia & borealis & 678 & 438 & 1.148 & 2 & Oblong & Multiple & $46-70$ \\
\hline Triconia & similis & 750 & 510 & 1.786 & 2 & & & 17 \\
\hline Oncaea s.l. & grossa & 795 & 557 & 2.306 & 2 & Oval & $2-3 / 2-3$ & $12-30$ \\
\hline Oncaea s. str. & venusta f. venella & 800 & 538 & 2.085 & 2 & Oval & Multiple & $60-70$ \\
\hline Oncaea s. str. & media-group & $580-860$ & & & 2 & & & $20-62$ \\
\hline Oncaea s. str. & media-group & & & & 2 & & & $24-60$ \\
\hline Oncaea s. str. & media & 710 & 446 & 1.210 & 2 & Oval cl. & Multiple & 40 \\
\hline \multirow[t]{3}{*}{ Oncaea s. str. } & mediterranea & $980-1200$ & & & 2 & & & $41-60$ \\
\hline & & & & 2.580 & 2 & & & $2-116$ \\
\hline & & 1010 & 632 & 3.326 & 2 & Oval cl. & Multiple & 80 \\
\hline Oncaea s.l. & englishi & 1020 & 653 & 3.657 & 2 & 'Capsule like' & $1 / 1$ & $2-4$ \\
\hline \multirow[t]{2}{*}{ Oncaea s. str. } & venusta f. typica & 1200 & & & 2 & & & $73-79$ \\
\hline & & 1130 & 724 & 4.933 & 2 & Oval cl. & Multiple & $60-80$ \\
\hline Triconia & antarctica & 1260 & 806 & 6.733 & 2 & 'Circular cl.' & Multiple & 80 \\
\hline \multirow[t]{4}{*}{ Triconia } & conifera & $1100-1260$ & & & & & & $30-58$ \\
\hline & & $1000-1100$ & & & 1 & & & $54-61$ \\
\hline & & $980-1100$ & 714 & 4.738 & 2 & Oval cl. & Multiple & $14-26$ \\
\hline & & 1020 & 662 & 3.805 & 2 & & $1-2 / 1-2$ & 8 \\
\hline Triconia & inflexa & 1370 & 918 & 9.820 & 2 & 'Oblong $\mathrm{cl} .^{\prime c}$ & Multiple & 94 \\
\hline Triconia & canadensis & 1557 & 1060 & 14.902 & 2 & Oval & $2-3 / 2$ & $4-52$ \\
\hline \multicolumn{9}{|c|}{$\begin{array}{l}\text { Female carbon after G.-A. Paffenhöfer (pers. comm.) in: Kiørboe \& Sabatini (1994); egg size after Böttger-Schnack et al. } \\
\text { (1989) (values not included in regression analysis, see text) }\end{array}$} \\
\hline \multicolumn{9}{|c|}{ Egg diameter possibly underestimated (low magnification) } \\
\hline 'c...reaching be & jond posterior edge & of caudal ra & mus' & & & & & \\
\hline
\end{tabular}




\begin{tabular}{|c|c|c|c|c|c|c|c|}
\hline Egg diar & & Egg weight & Clutch weight & & t ratio & Source & Remarks \\
\hline $\begin{array}{l}\text { range } \\
(\mu \mathrm{m})\end{array}$ & $\begin{array}{c}\text { mean } \\
(\mu \mathrm{m})\end{array}$ & $\begin{array}{c}\text { carbon } \\
\left(\mu \mathrm{g} 10^{-3}\right)\end{array}$ & $\begin{array}{c}\text { carbon } \\
\left(\mu g 10^{-3}\right)\end{array}$ & $\begin{array}{l}\text { egg/fem. } \\
\text { carbon }(\%)\end{array}$ & $\begin{array}{l}\text { clutch/fem. } \\
\text { carbon (\%) }\end{array}$ & & \\
\hline $40-46$ & 43.0 & 5.83 & 11.7 & 9.6 & 19 & 4 & \\
\hline $30-44$ & 37.5 & 3.87 & $38.7-61.9$ & 2.4 & $24-38$ & 12 & \\
\hline 45 & 45.0 & 6.68 & 26.7 & 5.9 & 24 & $4,11,12$ & \\
\hline 40 & 40.0 & 4.69 & $46.9-56.3$ & 1.3 & $13-16$ & 6 & \\
\hline $40-50$ & 45.0 & 6.68 & 53.4 & 1.7 & 13 & 12 & \\
\hline $38-45$ & 41.0 & 5.02 & 20.1 & 1.5 & 5.9 & 12 & \\
\hline 40 & 40.0 & 4.69 & $37.5-75.1$ & 1.1 & $8.8-18$ & 4,12 & \\
\hline $44-64$ & 54.0 & 11.54 & 162 & 3.0 & 42 & 4,12 & \\
\hline $45-55$ & 50.0 & 9.16 & 147 & 2.2 & 35 & 10 & \\
\hline 50 & 50.0 & 9.16 & $183-220$ & 2.2 & $43-52$ & 8 & Southern RS \\
\hline $48-54$ & 51.0 & 9.72 & $156-175$ & 1.6 & $26-29$ & 12 & Adriatic Sea \\
\hline $40-45$ & 42.5 & 5.63 & 67.5 & 1.0 & 12 & 4 & Central $\mathrm{RS}^{\mathrm{b}}$ \\
\hline $52-67$ & 59.5 & 15.44 & 232 & 1.4 & 21 & 12 & Northern RS \\
\hline & & & & & & $\begin{array}{l}8 \\
1\end{array}$ & Southern RS. Gulf of Aden \\
\hline $48-56$ & 52.0 & 10.31 & $227-247$ & 1.5 & $32-35$ & 4,12 & \\
\hline 60 & 60.0 & 15.83 & $63.3-95.0$ & 2.2 & $8.9-13$ & 6 & \\
\hline 55 & 55.0 & 12.20 & 366 & 1.2 & 35 & 6 & \\
\hline $60-75$ & 67.5 & 22.54 & $361-451$ & 2.7 & $43-53$ & 7 & \\
\hline $57-78$ & 65.0 & 20.13 & $221-241$ & 1.7 & $19-21$ & 14 & \\
\hline $50-60$ & 55.0 & 12.20 & 97.6 & 1.3 & 11 & 6 & \\
\hline $40-48$ & 44.0 & 6.24 & $187-250$ & 0.7 & $20-27$ & 4,8 & \\
\hline $39-62$ & 49.0 & 8.62 & $396-604$ & 0.8 & $34-52$ & 14 & \\
\hline & & & & & & 3 & \\
\hline $54-80$ & 67.0 & 22.05 & $265-661$ & 1.0 & $11-29$ & 14 & \\
\hline $40-50$ & 45.0 & 6.68 & $401-468$ & 0.3 & $19-22$ & 4,8 & \\
\hline & & & & & & 1 & \\
\hline & & & & & & 13 & \\
\hline $40-46$ & 43.0 & 5.83 & 233 & 0.5 & 19 & 8,12 & \\
\hline & & & & & & 1 & \\
\hline & 57.5 & 13.94 & $27.9-1620$ & 0.5 & $1.1-63$ & 5 & ${ }^{\mathrm{a}}$ See footnote \\
\hline $50-65$ & 57.5 & 13.94 & 1110 & 0.4 & 34 & 4,9 & \\
\hline $129-155$ & 142.0 & 209.89 & $420-840$ & 5.7 & $11-23$ & 2,15 & $\begin{array}{l}\text { Egg size calcul. after Heron } \\
(1977) \text {, her Fig. } 25 n\end{array}$ \\
\hline & & & & & & 3 & \\
\hline $50-60$ & 55.0 & 12.20 & $732-976$ & 0.2 & $15-20$ & 8 & \\
\hline $52-77$ & 64.5 & 19.67 & 1570 & 0.3 & 23 & 2 & $\begin{array}{l}\text { Egg size calcul. after Heron } \\
(1977) \text {, her Fig. } 2 b\end{array}$ \\
\hline & & & & & & 1 & \\
\hline & & & & & & 3 & No. of egg sacs questioned \\
\hline $75-88$ & 81.5 & 39.68 & $556-1030$ & 0.8 & $12-22$ & 12 & Red Sea \\
\hline 80 & 80.0 & 37.53 & 300 & 1.0 & 7.9 & 12 & Eastern Mediterranean \\
\hline $71-77$ & 74.0 & 29.70 & 2790 & 0.3 & 28 & 2 & $\begin{array}{l}\text { Egg size calcul. after Heron } \\
(1977) \text {, her Fig. } 4 \mathrm{~g}\end{array}$ \\
\hline $86.5-117.5$ & 100.0 & 73.30 & $293-3811$ & 0.5 & $2.0-25$ & 14 & \\
\hline
\end{tabular}


et al. 2000) and from publications of the biological working teams (Cornils 2001, Grossart \& Simon 2002, Häse et al. 2000).

Egg size measurements. For the compilation of egg vs. female sizes of oncaeid copepods (Table 1), published data as well as newly collected data of various oncaeid species were used. Unpublished data of 4 oncaeid species from the Pacific, which were kindly made available by Y. Nishibe (pers. comm.), were also included in the list. For several oncaeid species, these are the first data on their egg sizes and numbers and, with the exception of Epicalymma sp., which carried an unpaired egg sac, all species had 2 sacs attached to the genital opening. Egg size (diameter) was usually measured under a stereomicroscope with an eye piece micrometer at a magnification of $400 \times$, assuming the eggs were spherical. Egg sizes provided by Y. Nishibe were measured as greatest width and length of the egg, assuming an ovoid form; in this case the average width and length was used as an estimate of diameter for comparison.

Biomass estimates. Female carbon weight $\left(F_{\mathrm{C}}\right.$ in $\mu \mathrm{g}$ C female ${ }^{-1}$ ) was calculated from cephalothorax length $(\mathrm{CL}$, in $\mu \mathrm{m})$ of females using the length-carbon regression reported for epipelagic Oncaea spp. from the tropical Indian Ocean (Andaman Sea) by Satapoomin (1999):

$$
\ln F_{\mathrm{C}}=2.9 \ln \mathrm{CL}-17.5
$$

The results were compared to those from a length to ash-free dry wt (AFDW) regression obtained for juvenile and adult Oncaea spp. (mainly O. mediterranea) from the tropical Atlantic by Webber \& Roff (1995), whose CI-CII are of the same size as adult $O$. bispinosa:

$$
\ln F_{\mathrm{AFDW}}=2.1 \ln \mathrm{CL}-11.63
$$

which were converted to carbon assuming a carbon content of 37 \% AFDW (Båmstedt 1986, his Table 1.13, mean value for epipelagic copepods of low latitudes).

Egg carbon weight $\left(E_{C}\right.$, in $\left.\mu \mathrm{g} C\right)$ was estimated from the egg volume $\left(V\right.$, in $\left.\mu \mathrm{m}^{3}\right)$ assuming a carbon content of $0.14 \times 10^{-6} \mu \mathrm{g} \mathrm{C} \mu \mathrm{m}^{-3}$ as reported by Kiørboe et al. (1985) and used by several authors in subsequent studies (Kiørboe \& Sabatini 1994, 1995, Sabatini \& Kiørboe 1994, Hopcroft \& Roff 1998, Hirst \& Kiørboe 2002). The differing relationships between $V$ and $E_{\mathrm{c}}$ of marine copepods given by Huntley \& Lopez (1992):

$$
E_{\mathrm{C}}=0.139(V)-0.002 \quad\left(V_{1} \times 10^{6} \mu \mathrm{m}^{3}\right)
$$

and by Uye \& Sano (1995)

$$
E_{\mathrm{C}}=5.32 \times 10^{-8} \times \mathrm{ED}^{3.04}
$$

where ED is egg diameter in $\mu \mathrm{m}$, were both utilized for calculating the egg carbon contents, and the results were compared with those from a recalculated regression line of egg carbon on egg volume based on the data given in Table 1 of Huntley \& Lopez (1992).

Egg production rate (EPR, no. of eggs per female $\mathrm{d}^{-1}$ ) of Oncaea bispinosa in the field was calculated according to the egg-ratio method (Edmondson et al. 1962) using:

$$
\mathrm{EPR}=N_{\text {egg }} /\left(N_{\text {female }} \times D\right)
$$

where $N_{\text {egg }}$ and $N_{\text {female }}$ are the abundance of eggs and females, respectively, in the water column and $D$ is the temperature-dependent egg developmental time. According to Sazhina (1985), Hirakawa (1995), Webber \& Roff (1995) and Hopcroft \& Roff (1996), the egg developmental times of (larger) oncaeid species vary between 1.2 and $7 \mathrm{~d}$ for an ambient sea temperature of 20 to $28^{\circ} \mathrm{C}$. This temperature range was observed in the Red Sea during the study period at the surface and includes the constant and unusually high temperatures of 21.0 to $21.7^{\circ} \mathrm{C}$ at all layers below $150 \mathrm{~m}$ down to $800 \mathrm{~m}$. To assess the range of uncertainty in the estimation of $O$. bispinosa EPR, values were calculated for egg developmental times of 1 and $7 \mathrm{~d}$.

\section{RESULTS}

\section{Environmental conditions}

The study sites in the Red Sea represented 2 hydrographically distinct regimes during early spring. In the northern Red Sea, the water column was vertically stratified, with a shallow mixed upper layer and a weak thermogradient at about 50 to $100 \mathrm{~m}$. In the Gulf of Aqaba, deep vertical mixing occurred down to a depth of 350 to $400 \mathrm{~m}$; the vertical extension of the mixed layer increased with increasing distance from the Red Sea proper towards the northern Gulf of Aqaba. Surface temperatures decreased from $23^{\circ} \mathrm{C}$ in the northern Red Sea to $\sim 20^{\circ} \mathrm{C}$ in the northern Gulf of Aqaba, and salinities at the surface increased from 40.2 to 40.6 concurrently. In both subareas, the homogeneous deep water body was characterized by constant high temperatures of $21.0^{\circ} \mathrm{C}$ (Gulf of Aqaba) and $21.7^{\circ} \mathrm{C}$ (Red Sea) and high salinities of $>40.5$, as typically found in this area (Edwards 1987). In the Gulf of Aqaba, the entire water column was well oxygenated, whereas in the northern Red Sea oxygen concentrations were high (saturated) only at the surface and a strong $\mathrm{O}_{2}$ gradient occurred between 100 and $300 \mathrm{~m}$ (Häse et al. 2000). The core of the oxygen minimum zone with less than $60 \%$ saturation was situated between 300 and 500/600 m depth, as typically found in this area (Edwards 1987). 
The vertical distribution of chlorophyll a (chl a) reflected the differences in stratification: in the northern Red Sea and the southern Gulf of Aqaba, surface chl a concentrations increased from the surface down to a deep chl a maximum of up to $0.5 \mathrm{\mu g} \mathrm{l}^{-1}$ in the range of 50 to $100 \mathrm{~m}$ depth, whereas in the northern Gulf of Aqaba, chl a concentrations were distributed more homogeneously in the upper $300 \mathrm{~m}$ (Richter 2000, Cornils 2001).

\section{Egg sac morphology}

Two single females of Oncaea bispinosa were recorded with egg sacs still attached (Fig. 2A). One was found in the northern Red Sea at 500 to $550 \mathrm{~m}$ depth and the other in the southern Gulf of Aqaba at 600 to $750 \mathrm{~m}$. These specimens allowed us to define the characteristics of the egg sacs. They are produced in pairs and have an oblong form, which measures ca. $130 \mu \mathrm{m}$ in length and ca. $60 \mu \mathrm{m}$ in width; each sac contains 5 to 8 eggs (Fig. 2B,C), with an egg diameter of between 30 and $44 \mu \mathrm{m}$ (mean $=37.5 \mu \mathrm{m})$. The single eggs were usually transparent and arranged in a double row in 1 layer (Fig. 2B,C). Among the various types of egg sacs occurring in the samples, 2 were similar in morphology to those of $O$. bispinosa. The first egg sac type measured ca. $120 \mu \mathrm{m}$ in total length and ca. $65 \mu \mathrm{m}$ in width, usually containing 4 eggs with a diameter of 44 to $53 \mu \mathrm{m}($ mean $=48 \mu \mathrm{m})$; in some sacs 5 or even 6 eggs were found. This type belongs to O. cristata, Böttger-Schnack, an abundant small oncaeid of the ovalis-group, described recently (Böttger-Schnack 2005). The second egg sac type had an overall length of 150 to $160 \mu \mathrm{m}$ and a width of ca. $80 \mu \mathrm{m}$, containing 6 to 7 eggs with a diameter of 44 to $60 \mu \mathrm{m}$ (mean = $52 \mu \mathrm{m}$ ) arranged in 1 to 2 layers; this type has not yet been identified. Both egg sac types were more compact than those of $O$. bispinosa, and the eggs were opaque in transmitted light. Thus identification was clear-cut. No male-female pairs of $O$. bispinosa were observed in mating position.

\section{Population structure and vertical distribution of Oncaea bispinosa}

Adult and juvenile copepods

The standing stock of total Oncaea bispinosa varied 4 -fold regionally, with maximum and minimum values in the central and northern Gulf of Aqaba, respectively (Table 2). Some regional shift in population structure was indicated, with higher proportions of males and late juveniles in the central and northern Gulf of

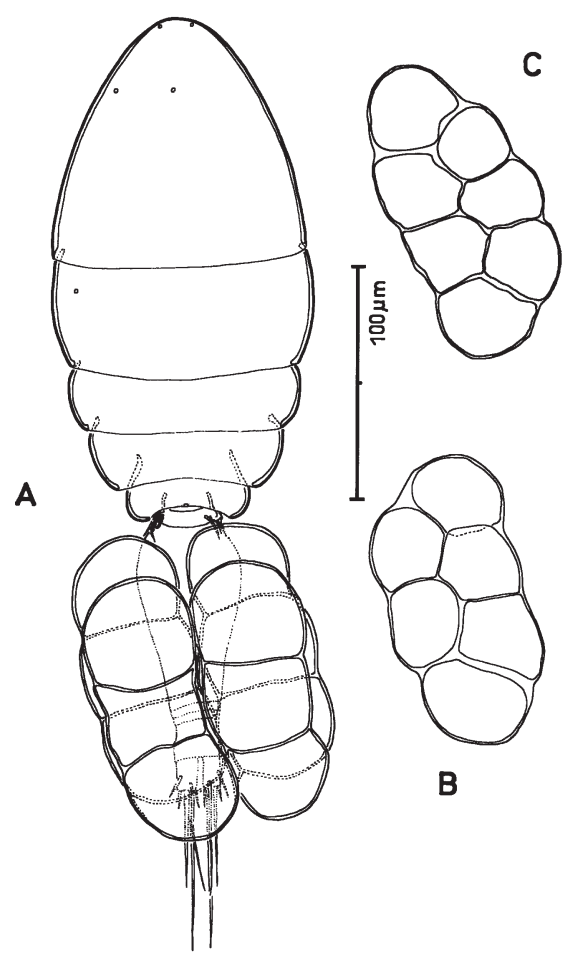

Fig. 2. Oncaea bispinosa (Copepoda, Oncaeidae), Red Sea. (A) Female with egg-sacs, dorsal; $(B, C)$ detached egg sacs, showing variation in egg numbers per sac

Aqaba. However, as the abundance of late juveniles was underestimated in the southern Gulf of Aqaba and the northern Red Sea (see 'Materials and methods'), the regional shift in the proportion of juveniles may be biased to an unknown degree. Within the copepod community, adult $O$. bispinosa accounted for 11-26\% of total Oncaeidae in the area, which is equivalent to $3-8 \%$ of total copepod numbers, excluding nauplii (Table 3). When also including late juveniles, the proportion of the species increases to $20-37 \%$ within the Oncaeidae and 7-12\% within total copepodids. This species thus appears to be one of the most abundant copepod species in the area investigated.

The vertical distribution of adult and juvenile Oncaea bispinosa is depicted in Fig. 3. Females usually exhibited a bimodal distribution pattern, with a less abundant epipelagic population occurring at 0 to $100 \mathrm{~m}$, while the largest part of the population occurred between 150 and $450 \mathrm{~m}$ depth. A distinct regional trend is indicated in the vertical distribution of females, related to differences in the hydrographical conditions: in the vertically mixed regime of the central Gulf of Aqaba, the mesopelagic population centre at 400 to $500 \mathrm{~m}$ occurred about $100 \mathrm{~m}$ deeper than in the stratified northern Red Sea (200 to $300 \mathrm{~m})$. In the northern Gulf of Aqaba, the vertical extension of the mesopelagic population centre of females may not 
Table 2. Oncaea bispinosa. Population structure in the northern Red Sea (NRS) and the Gulf of Aqaba (GA) during spring. Abundance ( $\mathrm{n}=$ individuals beneath $0.25 \mathrm{~m}^{2}$ in the water column) of females, males and late juveniles, and percentages $(\%)$ of the total numbers

\begin{tabular}{|c|c|c|c|c|c|c|c|c|}
\hline \multirow[t]{2}{*}{ Region } & \multirow{2}{*}{$\begin{array}{l}\text { Depth } \\
\text { (m) }\end{array}$} & \multicolumn{2}{|c|}{ Females } & \multicolumn{2}{|c|}{ Males } & \multicolumn{2}{|c|}{ Late juveniles } & \multirow{2}{*}{$\begin{array}{c}\text { Total } \\
\mathrm{n}\end{array}$} \\
\hline & & $\mathrm{n}$ & $\%$ & $\mathrm{n}$ & $\%$ & $\mathrm{n}$ & $\%$ & \\
\hline NRS & $0-750$ & 6320 & 60.4 & 3150 & 30.1 & 990 & 9.4 & 10500 \\
\hline GA-South & $0-750$ & 7900 & 57.7 & 2900 & 21.3 & 2900 & 21.0 & 14000 \\
\hline GA-Central & $0-800$ & 14500 & 35.2 & 14000 & 34.1 & 12000 & 30.7 & 40000 \\
\hline GA-North & $0-450^{\mathrm{a}}$ & 4600 & 28.0 & 3600 & 22.0 & 8200 & 50.0 & 16000 \\
\hline
\end{tabular}

Table 3. Abundance ( $\mathrm{n}=$ individuals beneath $0.25 \mathrm{~m}^{2}$ in the water column) of total copepods (excluding nauplii) and total Oncaeidae in the northern Red Sea (NRS) and the Gulf of Aqaba (GA) during spring, and proportion of Oncaea bispinosa (\% of total numbers) within the respective group. juv. = juveniles

\begin{tabular}{|c|c|c|c|c|c|c|c|}
\hline Region & $\begin{array}{l}\text { Depth } \\
\text { (m) }\end{array}$ & $\begin{array}{l}\text { Total } \\
\text { copepods } \\
\left(\times 10^{3}\right)\end{array}$ & $\begin{array}{l}O \\
\text { adults } \\
(\%)\end{array}$ & $\begin{array}{l}\text { bispinosa } \\
\text { adults+late juv. } \\
\qquad(\%)\end{array}$ & $\begin{array}{c}\text { Total } \\
\text { Oncaeidae } \\
\left(\times 10^{3}\right)\end{array}$ & $\begin{array}{r}O \\
\text { adults } \\
(\%)\end{array}$ & $\begin{array}{l}\text { bispinosa } \\
\text { adults+late juv. } \\
\qquad(\%)\end{array}$ \\
\hline NRS & $0-750$ & 130 & 7.3 & 8.0 & 51 & 18.5 & 20.4 \\
\hline GA-South & $0-750$ & 160 & 6.8 & 8.5 & 47 & 23.1 & 29.4 \\
\hline GA-Central & $0-800$ & 340 & 8.2 & 11.8 & 110 & 25.7 & 37.1 \\
\hline GA-North & $0-450^{a}$ & 250 & 3.3 & 6.6 & 73 & 11.3 & 22.5 \\
\hline
\end{tabular}
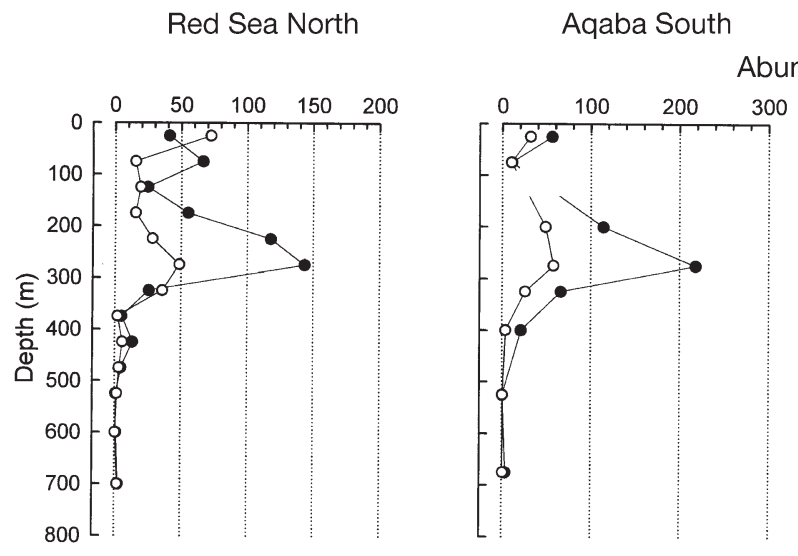

\section{Abundance (ind. $\mathrm{m}^{-3}$ )}
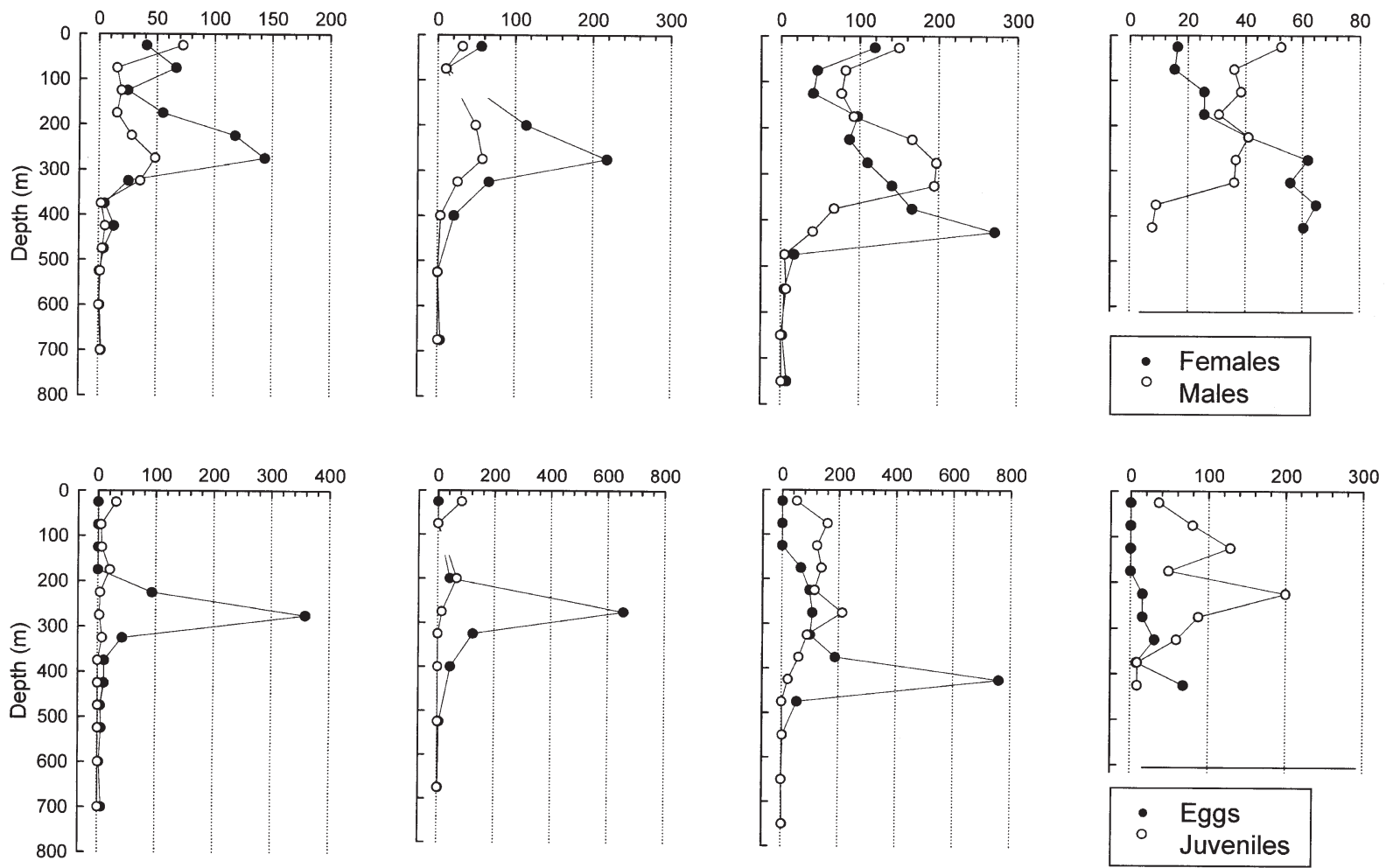

Fig. 3. Oncaea bispinosa. Vertical distribution of adults, late juveniles and total egg numbers along a transect from the northern Red Sea to the Gulf of Aqaba. Dots represent midpoints of consecutive depth ranges; at station 'Aqaba South' depth range 100 to $150 \mathrm{~m}$ is missing. Note the different scales 
have been fully assessed due to the limitations in the sampling strategy (no samples below $450 \mathrm{~m}$ depth). Males and females had very similar vertical patterns in the northern Red Sea and southern Gulf of Aqaba, but further north in the Gulf of Aqaba the mesopelagic population of males tended to occur at depths about $100 \mathrm{~m}$ shallower than female populations (Fig. 3). The sex ratio changed considerably with depth: in the epipelagic zone, males were equally abundant or even more numerous than females, whereas the proportion of females increased towards depths of 300 to $450 / 500 \mathrm{~m}$, where females outnumbered males by a factor of 3 to 6 . The distribution of late juveniles was more variable than that of adults, and they tended to be distributed shallower than the mesopelagic females (Fig. 3), indicating some ontogenetic vertical migration.

Egg sacs and total egg numbers

The abundance of egg sacs of Oncaea bispinosa in the entire water column varied regionally by 1 order of magnitude, from 272 to 2700 sacs beneath $0.25 \mathrm{~m}^{2}$ (Table 4); maximum and minimum numbers were found in the central and northern Gulf of Aqaba, respectively, which corresponds to the changes in total numbers of females (cf. Table 2). The average number of eggs per sac (calculated for the entire water column) was similar at all sites (6.27 to 6.44), and total egg numbers of $O$. bispinosa ranged from 1700 to 17000 eggs beneath $0.25 \mathrm{~m}^{2}$ (Table 4 ).

The vertical distribution of detached egg sacs and total egg numbers reflected the distribution pattern of mesopelagic females: in the northern Red Sea and the southern Gulf of Aqaba, maximum concentrations of eggs occurred at 250 to $300 \mathrm{~m}$, whereas in the central and northern Gulf of Aqaba, peak abundances of eggs were found about $150 \mathrm{~m}$ deeper, at 400 to $450 \mathrm{~m}$ (Fig. 3). In the epipelagic zone, between 0 and $150 \mathrm{~m}$, egg sacs of $O$. bispinosa were not found at any station.

\section{Ovigerous females}

The estimated proportion of ovigerous females varied between 3 and $12 \%$ of total female numbers in the entire water column (Table 4). Again, lowest values were found in the northern Gulf. In the vertical direction, the proportion of ovigerous females increased with depth from zero values in the epipelagic zone to maximum values of ca. 9 to $24 \%$ in depth layers between 250 and $450 \mathrm{~m}$ (Table 4).

\section{Egg and female carbon weight and production estimates of Oncaea bispinosa}

Single egg carbon content of Oncaea bispinosa was calculated as $3.9 \mathrm{ng} \mathrm{C}$, and total clutch carbon ranged from 39 to $62 \mathrm{ng}$ female $^{-1}$ (Table 5), based on the carbon-to-volume ratio reported by Kiørboe et al. (1985). Body carbon weight of a female O. bispinosa was calculated according to Satapoomin (1999) as $162 \mathrm{ng}$ C. Thus, egg carbon amounted to $2.4 \%$ of female body carbon, and clutch carbon ranged from 24 to $38 \%$ of female carbon (Table 5).

The egg carbon estimate of Oncaea bispinosa is slightly lower (3.2 ng) when using the equation given by Uye \& Sano (1995) and even less than half the value given above (1.8 ng) when applying the relationship of Huntley \& Lopez (1992). The resulting egg to female carbon weight ratios are correspondingly lower (Table 5). The latter equation, however, includes an intercept and cannot be extrapolated to the size range of small oncaeids. Thus, the same data presented in Table 1 of Huntley \& Lopez (1992) were used to calculate a linear regression forced through the origin (Fig. 4):

$$
E_{\mathrm{C}}=0.1496(V)
$$

This function provides an equally good fit to the data and a similar high degree of determination $\left(\mathrm{r}^{2}=0.96\right)$ and presents a very similar carbon-to-volume ratio as reported by Kiørboe et al. (1985). Inclusion of additional data on egg carbon reported by McKinnon \& Thorrold (1993) did not change the picture (Fig. 4). The corresponding carbon weight of single eggs of Oncaea bispinosa would amount to $4.1 \mathrm{ng}$ or $2.5 \%$ of female carbon (Table 5).

Table 4. Oncaea bispinosa. Abundance of egg sacs and total eggs (numbers beneath $0.25 \mathrm{~m}^{2}$ in the given depth layer) and proportions of ovigerous females ( $\%=$ percentage of total female numbers) in the northern Red Sea (NRS) and Gulf of Aqaba (GA) during spring

\begin{tabular}{|lccccc|}
\hline Region & $\begin{array}{c}\text { Depth } \\
(\mathrm{m})\end{array}$ & $\begin{array}{c}\text { Egg } \\
\text { sacs }\end{array}$ & $\begin{array}{c}\text { Average no. } \\
\text { eggs per sac }\end{array}$ & $\begin{array}{c}\text { Total } \\
\text { eggs }\end{array}$ & $\begin{array}{c}\text { Ovigerous } \\
\text { females (\%) }\end{array}$ \\
\hline Total water column & & & & \\
NRS & $0-750$ & 1100 & 6.24 & 6800 & 8.6 \\
GA-South & $0-750$ & 1900 & 6.44 & 12000 & 12.0 \\
GA-Central & $0-800$ & 2700 & 6.37 & 17000 & 9.7 \\
GA-North & $0-450^{\text {a }}$ & 270 & 6.29 & 1700 & 3.0 \\
Layer of maximum egg numbers & & & \\
NRS & $250-300$ & 720 & 6.20 & 4500 & 20.0 \\
GA-South & $250-300$ & 1300 & 6.40 & 8200 & 23.5 \\
GA-Central & $400-450$ & 1500 & 6.46 & 9500 & 21.7 \\
GA-North & $400-450^{\text {a }}$ & 130 & 6.63 & 850 & 8.5 \\
aDepth range & 450 to 600 m not sampled & & \\
\hline \multicolumn{7}{l}{} \\
\hline
\end{tabular}


Table 5. Oncaea bispinosa. Comparison of egg and female carbon weight, calculated using different equations from the literature. Female body carbon alternatively taken as (A) $162 \mathrm{ng}$, based on Satapoomin (1999), and (B) $281 \mathrm{ng}$, based on Webber \& Roff (1995; derived from dry weight; using conversion factor of Båmstedt 1986). $E_{\mathrm{C}}=$ egg carbon; $V=$ volume; $E_{\mathrm{d}}=$ egg diameter; $F_{\mathrm{c}}=$ female carbon; $C l_{\mathrm{c}}=$ clutch carbon $; \mathrm{ng}=$ nanogram

\begin{tabular}{|c|c|c|c|c|c|c|}
\hline \multirow{2}{*}{$\begin{array}{l}\text { Eq. for } \\
E_{\mathrm{c}}(\mu \mathrm{g})\end{array}$} & \multicolumn{2}{|c|}{ Estimated egg carbon } & \multicolumn{4}{|c|}{ Egg/female carbon weight ratio (\%) } \\
\hline & (ng C per egg) & (ng C per clutch) & $\begin{array}{c}E_{\mathrm{c}} / F_{\mathrm{C}} \\
\text { (A) }\end{array}$ & $\begin{array}{c}C l_{\mathrm{c}} / F_{\mathrm{c}} \\
(\mathrm{A})\end{array}$ & $\begin{array}{c}E_{\mathrm{c}} / F_{\mathrm{C}} \\
\text { (B) }\end{array}$ & $\begin{array}{c}C l_{\mathrm{c}} / F_{\mathrm{c}} \\
\text { (B) }\end{array}$ \\
\hline $0.14 \times 10^{-6} V\left(\mu \mathrm{m}^{3}\right)^{\mathrm{a}}$ & 3.9 & $39.0-62.0$ & 2.4 & $24-38$ & 1.4 & $14-22$ \\
\hline $0.139 \times V\left(10^{6} \mu \mathrm{m}^{3}\right)-0.002^{\mathrm{b}}$ & 1.8 & $18.0-28.8$ & 1.1 & $11-18$ & 0.6 & $6.4-10$ \\
\hline $5.32 \times E_{\mathrm{d}}^{3.04}(\mu \mathrm{m})^{\mathrm{c}}$ & 3.2 & $32.0-51.2$ & 2.0 & $20-32$ & 1.1 & $11-18$ \\
\hline $0.1496 \times 10^{-6} V\left(\mu \mathrm{m}^{3}\right)^{\mathrm{d}}$ & 4.1 & $41.0-65.6$ & 2.5 & $25-40$ & 1.5 & $15-23$ \\
\hline
\end{tabular}

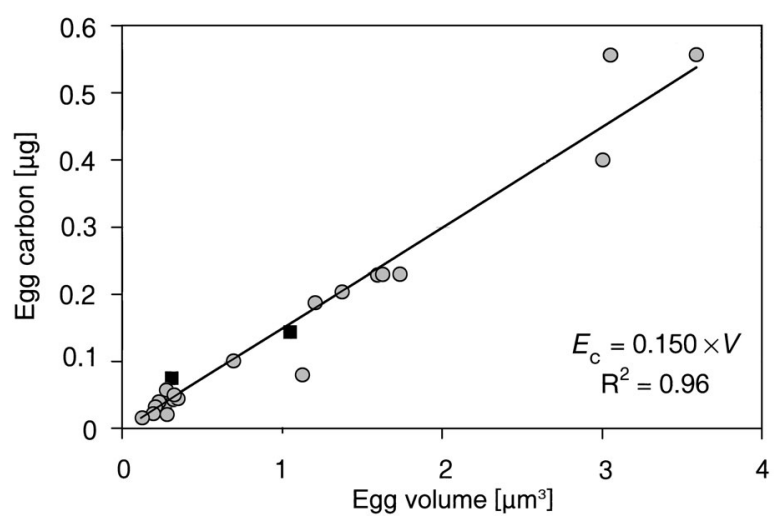

Fig. 4. Egg carbon $\left(E_{\mathrm{c}}\right)$ vs. egg volume $(V)$ of marine pelagic copepods, calculated after data listed in Table 1 of Huntley \& Lopez (1992). = data from McKinnon \& Thorrold (1993) presented for reference but not included in equation

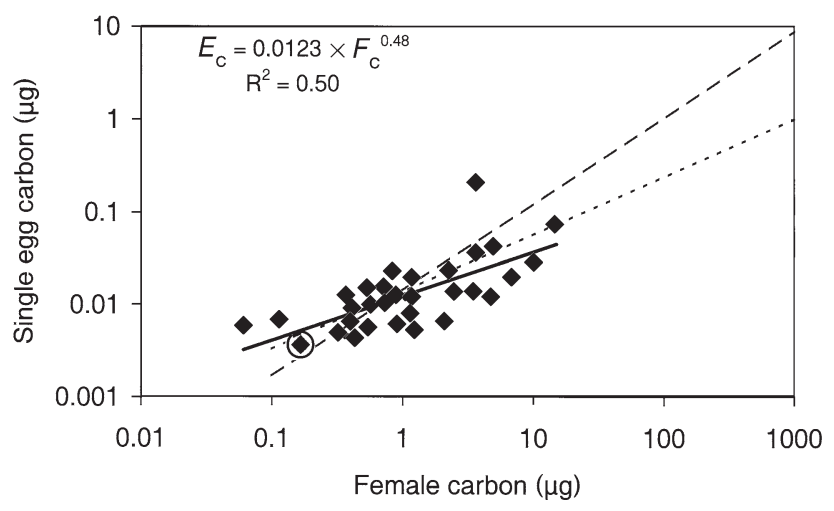

Fig. 5. Single egg carbon $\left(E_{\mathrm{c}}\right)$ vs. female carbon weight $\left(F_{\mathrm{c}}\right)$ of oncaeid copepods, calculated using the egg-carbon-to-eggvolume ratio of $0.14 \mathrm{ng} \mathrm{C} \mathrm{mm}^{-3}$ (Kiørboe et al. 1985) and the female size/carbon weight relationship of Satapoomin (1999). $\mathrm{O}=$ value of Oncaea bispinosa. Regressions from Kiørboe \& Sabatini (1995) for sac-spawning (----) and broadcastspawning (-- -) marine pelagic copepods are presented for reference
When using as an alternative estimate the cephalothorax length-dry wt relationship of Webber \& Roff (1995) and assuming a carbon content of $37 \%$ dry wt (Båmstedt 1986), the body carbon of a female Oncaea bispinosa would be estimated as $281 \mathrm{ng} \mathrm{C}$. In this case, the egg-to-female-carbon-weight ratios would be reduced by almost half compared to the first estimate (Table 5).

Table 1 presents a compilation of published and newly collected data on egg and female size, total numbers of eggs per female (= clutch size) and calculated egg and female carbon weight ratios of various oncaeid species between 0.2 and $1.5 \mathrm{~mm}$ body length, using the female biomass data after Satapoomin (1999) and applying the egg-carbon-tovolume ratio of Kiørboe et al. (1985). Within the Oncaeidae, single egg carbon $\left(E_{C}\right.$, in $\left.\mu g\right)$ increases with increasing female body carbon $\left(F_{\mathrm{C}}\right.$ in $\left.\mu \mathrm{g}\right)$, following the equation $E_{\mathrm{c}}=0.012 F_{\mathrm{c}}^{0.48}\left(\mathrm{r}^{2}=0.50, \mathrm{n}=\right.$ 33) (Fig. 5), and total clutch carbon $\left(\mathrm{Cl}_{\mathrm{c}}\right)$ to female carbon can be expressed by the equations $C l_{\mathrm{C}}=$ $0.241 F_{\mathrm{C}}{ }^{1.02}\left(\mathrm{r}^{2}=0.85\right)$ and $C l_{\mathrm{c}}=0.166 F_{\mathrm{c}}^{0.79}\left(\mathrm{r}^{2}=0.62\right)$ for maximum and minimum clutch carbon estimates respectively (Fig. 6).

EPR, derived from the observed fraction of eggbearing females and published data on egg developmental times (see 'Materials and methods'), were estimated first as averages over the entire water column. At the 4 stations studied, the values for Oncaea bispinosa range between 0.05 and 0.22 eggs per female $\mathrm{d}^{-1}(\mathrm{e} / \mathrm{f} / \mathrm{d})$ when assuming an egg developmental time of $7 \mathrm{~d}$ and between 0.37 and $1.5 \mathrm{e} / \mathrm{f} / \mathrm{d}$ when assuming a $1 \mathrm{~d}$ developmental time (Table 6). The highest value is indicated for the southern Gulf of Aqaba station and the lowest for the northern Gulf of Aqaba station. Resolving vertical differences, the maximum EPR is about 2 to 3 times higher than the average for the whole depth range (Table 6). 


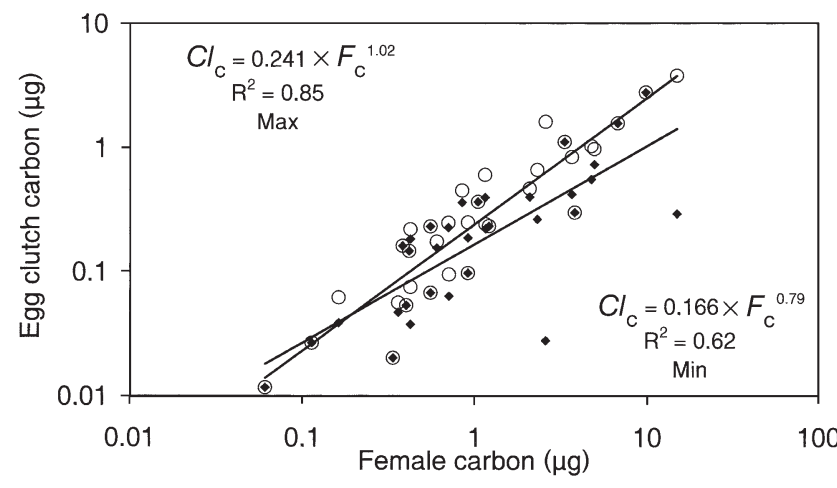

Fig. 6. Maximum (O) and minimum $(\bullet)$ estimate of total egg (= clutch) carbon $\left(C l_{c}\right)$ vs. female carbon weight $\left(F_{c}\right)(\mu g C)$ of oncaeid copepods

Table 6. Oncaea bispinosa. Ranges for estimates of egg production rate $\left(E P R=\right.$ eggs per female $\left.d^{-1}\right)$ in the northern Red Sea (NRS) and the Gulf of Aqaba (GA) assuming developmental times of 1 to $7 \mathrm{~d}$

\begin{tabular}{|lccc|}
\hline Region & $\begin{array}{c}\text { Average EPR } \\
0-750 / 800 \mathrm{~m}\end{array}$ & $\begin{array}{c}\text { Maximum } \\
\text { EPR }\end{array}$ & $\begin{array}{c}\text { Depth of max. } \\
\text { EPR (m) }\end{array}$ \\
\hline NRS & $0.15-1.08$ & $0.36-2.49$ & $250-300$ \\
GA-South & $0.22-1.54$ & $0.43-3.01$ & $250-300$ \\
GA-Central & $0.18-1.23$ & $0.40-2.80$ & $400-450$ \\
GA-North & $0.05-0.37^{\mathrm{a}}$ & $0.16-1.12$ & $400-450$ \\
a Depth range 0 to $450 \mathrm{~m}$ & & \\
\hline
\end{tabular}

\section{DISCUSSION}

\section{Methodological considerations}

Field data. The actual abundance of Oncaea bispinosa egg sacs may in general have been underestimated to some extent in the present study because their width (ca. $60 \mu \mathrm{m})$ is slightly smaller than the diagonal of a $0.055 \mathrm{~mm}$ mesh of the sampling net (i.e. $0.078 \mathrm{~mm}$ ), and thus it cannot be excluded that individual detached egg sacs were lost through the meshes. In addition, in the northern Gulf of Aqaba, the total abundance of $O$. bispinosa was underestimated because the samples were restricted to the upper $450 \mathrm{~m}$ of the water column, not including the deeper layers down to the bottom at $600 \mathrm{~m}$ depth. The bias should be less than $25 \%$ for total abundance and insignificant for reproduction rate, as it is not to be expected that density and the share of ovigerous females are higher in these depth layers than in the sampled depth range.

Biomass estimates. Egg carbon: For marine planktonic copepods an egg carbon content of $0.14 \times 10^{-6} \mu \mathrm{g}$ C $\mu \mathrm{m}^{-3}$ reported by Kiørboe et al. (1985) has been widely adopted in the literature (e.g. Kiørboe \& Sabatini 1994, 1995, Sabatini \& Kiørboe 1994, Nielsen \&
Sabatini 1996, Hopcroft \& Roff 1998, Hirst \& Kiørboe 2002). However, this conversion factor is not based on original data of Kiørboe et al. (1985) but has been calculated from published data on the egg carbon content of Paracalanus parvus (Checkley 1980) and for 2 species of Acartia (Uye 1981). Therefore, its applicability to other copepod groups, in particular non-calanoid taxa, appears questionable. Nevertheless, the conversion factor has been used in the present paper for the purpose of comparison (Table 1). The relationship presented by Huntley \& Lopez (1992, their Table 1) is based on egg carbon values from a larger variety of marine calanoid copepod species (mostly broadcast spawners). It appears to be very similar to that suggested by Kiørboe et al. (1985), but, due to its intercept, it leads to substantially reduced carbon values for very small eggs like those of Oncaea bispinosa. The intercept, however, could well be avoided as the fit to the data is not reduced when forcing the regression through the origin, which provides a very similar carbon-to-volume relation as presented by Kiørboe et al. (1985). Inclusion of additional data on egg carbon reported by McKinnon \& Thorrold (1993) does not change the picture. The relationship reported by Uye \& Sano (1995) results in somewhat lower egg carbon values than those calculated in accordance with Kiørboe et al. (1985), but the difference is less than $16 \%$ for the given size range of eggs. In sum, it can be stated that the different relationships presented in the literature to calculate egg carbon content from egg size lead to very similar values if also properly adapted for small egg-bearing marine copepods. Nevertheless, the actual values obtained from this extrapolation to the small size range must still be confirmed.

Female carbon: Converting length of Oncaea bispinosa to dry weight (in accordance with Webber \& Roff 1995) and dry weight to carbon using the most relevant factor 0.37 of Båmstedt (1986), this value is about twice as high as a corresponding value from the lengthcarbon regression of Satapoomin (1999). Thus, the length-based weight estimates for females of small species appear to be more uncertain than egg weight estimates on the basis of presently available information.

In addition to size, seasonal and habitat differences in carbon content of marine pelagic copepods and their eggs must be considered as well. For epipelagic copepods in low latitudes, Båmstedt (1986) reported a carbon content of $\sim 37 \%$ AFDW, whereas for deep dwelling copepods this value was significantly higher, amounting to about 52\%; for mesopelagic Oncaeidae even greater carbon values of about $60 \%$ dry wt have been observed (Y. Nishibe \& T. Ikeda pers. comm.). The carbon content of copepod eggs may vary considerably between seasons for a given 
volume (independent of size), e.g. as in the subtropical Acrocalanus gibber, which differed by a factor of $\sim 3$ (0.08 to $0.28 \times 10^{-6} \mu \mathrm{g} \mathrm{C} \mu \mathrm{m}^{-3}$, McKinnon 1996, calculated in accordance with his Table 3). Thus, carbon weight should be presented as results only if directly measured, because conversions from different measures of biomass include a high degree of uncertainty when based on the relationships presently available for copepods.

\section{Egg sac morphology}

The egg sac of Oncaea bispinosa appears to be unique within the Oncaeidae, differing from all other species so far studied by the number and arrangement of eggs per sac (= egg sac form). Similar-sized oncaeids, such as Spinoncaea, have a much lower egg number (2 per sac) and larger egg size $(45 \mu \mathrm{m})$ than $O$. bispinosa, and the form of the egg sac is irregular (cf. Böttger-Schnack 2003, her Fig. 2K). The minute species of the vodjanitskii-group even carry only a single large egg per sac (Böttger-Schnack et al. 1989). Egg sacs of medium-sized and large oncaeid species ( $>0.5 \mathrm{~mm}$ female body length) usually have a 2- or multi-layered arrangement, giving them the appearance of an oval cluster (e.g. Giesbrecht 1892, plate 2, his Fig. 12, plate 3, his Fig. 7, plate 4, his Fig. 12, Heron 1977, her Fig. 4g, Ho 1984, his Fig. 12B, BöttgerSchnack \& Huys 2001, their Fig. 1A,B). Even for medium-sized species with comparatively low egg numbers, such as Triconia hawii, the form of the egg sac is slightly curved (Böttger-Schnack 1999, her Fig. 22J) and not plane as in $O$. bispinosa. The number and arrangement of eggs in the sac might be typical for different species groups within the Oncaeidae and thus might be an additional and useful tool for the recognition of different taxonomic groupings within the family.

Egg size is another characteristic which appears to differentiate Oncaea bispinosa from other oncaeids: they have the smallest eggs found in oncaeid copepods so far (cf. Table 1) and, apart from some benthic harpacticoids (Poulin 1995), the eggs are among the smallest observed in copepod species in general. However, the differences in egg sizes between the oncaeid species less than $0.5 \mathrm{~mm}$ in body length is apparently very small, and for group-specific differences egg number may be more relevant than egg size. In addition, it is not known to what extent the egg sizes of oncaeids vary among seasons and regions. For a freespawning calanoid copepod, Paracalanus indicus, McKinnon \& Duggan (2001) reported seasonal differences in egg size of $11 \%$ in a tropical study site. For the egg-carrying calanoid Pseudocalanus spp., egg sizes in temperate regions varied seasonally in correlation with female length, but less conspicuously so (7\% difference) than female size (35\% difference) (McLaren 1965). Size variation of oncaeid eggs might be assumed to be low, as the sizes of females appear to vary only slightly among seasons in subtropical regions (Riccardi \& Mariotto 2000).

The unequivocal identification of the typical egg sac of Oncaea bispinosa enables enumeration of detached sacs in plankton samples, thereby providing field data on the reproduction of this microcopepod by a simple method. Thus, further information on reproductive parameters for $O$. bispinosa and its sibling species O. zernovi, for which the same type of egg sac can be assumed, including temporal and spatial differences, might easily be obtained in future ecological studies for this important group of marine microcopepods.

\section{Population structure and vertical distribution of Oncaea bispinosa}

For adult Oncaea bispinosa, the abundance values and sex ratios reported here for spring are in the same order of magnitude as those previously reported for the summer period (Böttger-Schnack 1995 and unpubl. data). Values for autumn and winter are much lower for total abundance (Böttger-Schnack 1990a,b) and proportion of males (Böttger-Schnack et al. 1989) but are not directly comparable because they are based on sampling with a somewhat coarser mesh size of $0.1 \mathrm{~mm}$, which cannot sample even adults of this species (in particular the smaller males) quantitatively. Juvenile $O$. bispinosa had not been enumerated in previous studies. Within the Oncaeidae, the relative abundance of adult $O$. bispinosa appeared to be somewhat higher during spring (11-26\%) than during summer (11-17\%, Böttger-Schnack 1995), which is equivalent to $2-6$ or $3-8 \%$, respectively, of total copepods (excluding nauplii). This species appears to be of continuously high importance and can be regarded as one of the dominant oncaeid copepod species in the area, with even greater proportions than those given above, when including juveniles in the comparison.

The range of vertical distribution observed for Oncaea bispinosa during spring is generally similar to that found in other regions and during other seasons in the Red Sea (Böttger-Schnack 1990a,b, 1995). A bimodal distribution pattern (in particular of females) appears to be typical during stratified conditions of the water column (summer, autumn, northern Red Sea during spring), while during periods with a weakly stratified or mixed water column (winter, Gulf of Aqaba during spring) the species exhibits uni-, bi- or plurimodal vertical distribution patterns (Böttger- 
Schnack 1990a,b, 2002, this study). In deep oceanic areas, the bulk of the population is mostly found below a depth of 150 to $200 \mathrm{~m}$, whereas in shallow coastal areas $O$. bispinosa does not seem to have a constant depth preference (Böttger-Schnack 2002).

\section{Reproduction of Oncaea bispinosa}

The percentages of ovigerous females of Oncaea bispinosa observed during the present study ( 3 to $12 \%$ of total female numbers, ca. 9 to $24 \%$ for distinct vertical layers of maximum reproduction) appear to be lower than comparable data given by Moore \& Sander (1976) for 2 large oncaeid species from the Caribbean Sea (33 to $100 \%$ of adults in breeding conditions). This might be due to differences in the reproductive parameters considered. The proportion of females with attached spermatophores was minor in the present study and thus not considered. Furthermore, males with protruding spermatophores could not be observed due to the small size of the species, and male-female pairs have so far not been recorded in $O$. bispinosa (Böttger-Schnack et al. 1989, this study). Webber \& Roff (1995) suggested a 'reproductive index' (RI) and reported a value of 4.3 as a yearly mean for $O$. mediterranea at an oceanic site off Jamaica in the upper 0 to $200 \mathrm{~m}$. However, it is not clear from the explanations given in their method section whether this value represents the percentage of ovigerous females within the entire female population (i.e. $4.3 \%$ ovigerous females) or the ratio of abundances of ovigerous to non-ovigerous females, which in this case (4.3:1) would be equivalent to approx. $80 \%$ ovigerous females as a yearly average.

For 2 Antarctic oncaeid species, Oncaea curvata and O. antarctica, Metz (1996) reported values between 0 and $42 \%$ of ovigerous females in the 0 to $1000 \mathrm{~m}$ water column during 2 seasons. Between 2 and $36 \%$ of the female population carried attached spermatophores. The percentage values of eggbearing females in her study appear to be underestimated because only females with attached sacs were counted, whereas detached egg sacs in the samples were not considered. Thus, the maximum values of reproductive females for these 2 cold-water oncaeids appear to be much higher than those reported for the warm-water species $O$. bispinosa. This could be due to a more pronounced seasonality in cold-water species, but seasonality has also been observed in the Red Sea and Gulf of Aqaba (Kimor \& Golandsky 1977, Weikert 1987, Beckmann 1988, 1996, Lindell \& Post 1995), and for oncaeid copepods seasonality in cold water does not appear to be as pronounced as in calanoids (Atkinson 1998).
The vertical distribution of ovigerous females and egg numbers of Oncaea bispinosa in the Red Sea clearly indicate that reproduction occurs in the upper mesopelagic zone, whereas the minor epipelagic population appears to be non- or at least much less reproductive. The vertical shift in sex ratio between the epiand mesopelagic populations, with much higher proportions of males at shallower depth, may indicate that fertilization and egg development of $O$. bispinosa do not occur in the same depth layer. Fertilized females from the epi- or upper mesopelagic zones seem to sink to deeper layers, where the maximum proportion of ovigerous females has been found. A similar shift in sex ratio has been observed for $O$. bispinosa during summer (Böttger-Schnack 2002, her Fig. 6), indicating that reproduction might not be restricted to the spring season. A comparable sex-specific behavior has been reported for 2 other Red Sea oncaeids, O. mediterranea and O. scottodicarloi, showing an extended bimodal vertical distribution pattern in females, but not in males (Böttger-Schnack 1990a, O. scottodicarloi as $O$. media f. minor). For the diurnally migrating Triconia conifera, however, sex ratios were similar between the epipelagic (day) and the mesopelagic (night) zone; in addition, for typical mesopelagic oncaeids such as $O$. 'ovalis', which do not undertake diurnal vertical migrations, sex ratios are comparable to those of epipelagic species (Böttger-Schnack et al. 1989, unpubl. data). Thus, a vertical shift in sex ratio appears to be a specific strategy of certain species and cannot be generalized to all species in the family. An increase in male proportions with depth as reported by Paffenhöfer \& Mazzocchi (2003) for total Oncaeidae within the upper $100 \mathrm{~m}$ of the water column in the Sargasso Sea does not seem to be a general phenomenon in oncaeids but depends on the species structure of the community.

The depth layer of peak abundances of ovigerous females ( $=$ maximum reproduction) obviously depends on the vertical mixing regime of the areas investigated. In the northern Red Sea ovigerous females occurred at shallower depths than in the deeply mixed Gulf of Aqaba. As temperatures and salinities of the water column below $200 \mathrm{~m}$ are generally similar in both regions, factors other than temperature or salinity preference must be responsible for the observed vertical differences in the reproductive population. The main hydrographical difference is found in the oxygen concentrations: mesopelagic layers in the Red Sea are characterized by an extreme oxygen minimum zone, extending between 300 and $600 \mathrm{~m}$ depth, which strongly influences zooplankton vertical distribution (Weikert 1987). In contrast, in the Gulf of Aqaba, no oxygen minimum zone is found (Reiss \& Hottinger 1984). Thus, the occurrence of the 
reproductive population at shallower depths in the Red Sea proper might be indicative of an avoidance of the oxygen minimum zone. Other environmental factors, such as predator avoidance and/or distribution of associated organisms and food availability, should also be taken into account but were not investigated during the present study.

Juvenile Oncaea bispinosa occurred at somewhat shallower depths in the water column than ovigerous females, indicating that ontogenetic vertical migration might have occurred, although the few data available are not sufficient to draw more general conclusions. Comparative data on the vertical distribution of ontogenetic stages of oncaeid species are scarce because juvenile oncaeids are difficult to identify. The only study the present authors are aware of is on O. curvata in the Antarctic, for which an extensive ontogenetic vertical migration between the epi- and mesopelagic zone has been reported by Metz (1996), with juveniles being distributed at shallower depths (epipelagic) than adults (mesopelagic).

\section{Egg and female carbon weight of oncaeid copepods}

The regression of egg carbon on female carbon weight calculated for oncaeid copepods in the present study clearly differs from corresponding relationships published so far. Fig. 5 includes for comparison the relationships reported by Kiørboe \& Sabatini (1995), showing that the data for (egg-carrying) oncaeids fall in general into the range of data for egg-carrying non-oncaeids. However, the increase of egg carbon per unit female carbon (slope of regression) is lower for oncaeids and appears to be more similar to that of (larger) broadcasting calanoids. Kiørboe \& Sabatini (1995) concluded that there is a general relation between egg size and female size in all egg-carrying copepods. Though a common relation appears to be characteristic for some taxa of egg carriers, like the cyclopoid family Oithonidae and the few egg-bearing calanoids, the same relation does not apply to the poecilostome family Oncaeidae. Thus, the general conclusions on the 'scaling of fecundity' (as well as growth and development) in marine planktonic copepods drawn by Kiørboe \& Sabatini (1995) need to be reconsidered by including the numerous species of Oncaeidae (as well as Corycaeidae and Sapphirinidae), representing major groups of marine pelagic copepods not taken into account so far. In a more recent study on global rates and patterns of fecundity of marine planktonic copepods (Bunker \& Hirst 2004), the existing gap in our knowledge of the fecundity of oncaeids has been emphasized by explicitly excluding poecilostome copepods from their assumptions due to an insufficient data base.

For egg-bearing copepods, clutch to female carbon may be a more useful parameter when assessing female fecundity as discussed by Hopcroft \& Roff (1998). For individual species an inverse relationship between the number of eggs per clutch and single egg size has been reported (Mazzocchi \& Paffenhöfer 1998). Thus, clutch weight instead of egg weight may provide a more stable relation to female size, but comparable data are scarce.

\section{Estimated egg production rate of Oncaea bispinosa}

The present data provide for the first time an estimation of the reproduction capacity of a mesopelagic oncaeid microcopepod measured in the field. In general, hardly any population-specific EPR have been published for small-sized sac spawners in oceanic areas. From a subtropical shallow coastal area data are available for 2 small Oithona species. Their EPR values range from approx. 1 to $7 \mathrm{e} / \mathrm{f} / \mathrm{d}$ (McKinnon \& Ayukai 1996). For oncaeids, EPR data are available from laboratory studies (incubation method) and for larger oncaeid species of $>0.7 \mathrm{~mm}$ body length only. Such values reported for Oncaea mediterranea and $O$. venusta range from 5 to 15 e/f/d (Sazhina 1985, Paffenhöfer 1993, Hirakawa 1995, Webber \& Roff 1995). Similarly, EPR incubation data reported for nononcaeid sac-spawning microcopepods, such as species of Oithona (Paffenhöfer 1993, Uye \& Sano 1995) or Microsetella (Uye et al. 2002), range from 2.6 to $11.5 \mathrm{e} / \mathrm{f} / \mathrm{d}$. All these data extend to much higher values than even the maximum estimate obtained for the minute but abundant species $O$. bispinosa in the Red Sea (ca. 0.2 to $3.0 \mathrm{e} / \mathrm{f} / \mathrm{d}$ ). Though it cannot be excluded that the actual EPR data were underestimated to some extent in the present study, the 'methodological considerations' given above do not indicate any substantial bias compared to the differences shown here.

Comparing results for sac-spawning copepods includes the problem that data obtained from the incubation method usually refer to actively reproducing females only (e.g. Hopcroft \& Roff 1998), while in field studies the entire female population is taken into account, including both non-reproductive and reproductive specimens. Satapoomin et al. (2004), however, combined laboratory-derived EPR data (egg-hatching rate) with field-collected population data (in situ egg:female ratio) in order to estimate the egg production of 3 dominant representatives of epipelagic sac spawners (Oithona plumifera, Oncaea venusta and Euchaeta marinella). Mean egg production rate was 
highest for $O$. venusta (average $11.5 \mathrm{e} / \mathrm{f} / \mathrm{d}$ ), but the range of values was rather wide ( 0.6 to $38 \mathrm{e} / \mathrm{f} / \mathrm{d})$ due to seasonal and regional variations. It includes large parts of the range obtained for the other 2 species $(0.1$ to $11 \mathrm{e} / \mathrm{f} / \mathrm{d}$ ), and the ranges and averages for all 3 species extend to much higher values than calculated in the present study for $O$. bispinosa.

Despite the remaining uncertainties, the data presently available seem to indicate that EPR is rather low for Oncaea bispinosa and may also be so for other small oncaeids, which have much lower egg numbers per sac (see above). However, the total lifetime fecundity of the species is not necessarily lower than that of other epipelagic microcopepod taxa, as a reduced production rate may be compensated for by a longer lifetime of the females. In the laboratory, the warm-water $O$. mediterranea lived for up to $54 \mathrm{~d}$ despite insufficient feeding conditions (Paffenhöfer 1993), and the coldwater mesopelagic Triconia canadensis has recently been found to survive even for an extremely long period of $>130 \mathrm{~d}$ without any obvious food (Y. Nishibe pers. comm.). A low mortality, e.g. related to its pseudopelagic way of life (e.g. Green \& Dagg 1997), and association with gelatinous organisms potentially providing shelter against predation, may be the basis for oncaeid copepods to build up high population densities as observed in the Red Sea and elsewhere despite a low EPR.

In contrast to this view, a recent concept put forward by Hirst \& Kiørboe (2002) on the mortality in marine pelagic copepods, with temperature as the only driving force, would predict a rather high mortality for oncaeids. This concept is derived from data obtained for epipelagic calanoid and oithonid copepod taxa only and does not include the small species of the family Oncaeidae or any mesopelagic spawners. The life strategy of these groups may be sufficiently different to epipelagic taxa, as indicated above, and thus may not be compatible with the mortality concept of Hirst \& Kiørboe.

Acknowledgements. We thank Professor G. Hempel, the initiator and chief scientist of RV 'Meteor' cruise 44/2, and Professor W. Hagen and PD Dr. S. B. Schnack-Schiel, who collected the small mesh net plankton samples during the cruise. Sincere thanks are given to Dr. Y. Nishibe (Graduate School of Fisheries Sciences, Hokkaido University) for making available his unpublished data on egg and female sizes of oncaeid species from the subarctic Pacific. He and Professor T. Ikeda also provided unpublished data on chemical and reproductive parameters and the longevity of mesopelagic Oncaeidae, which were partly presented at the 3rd International Zooplankton Production Symposium, Gijon, Spain, 2003. The constructive comments of 3 anonymous referees are gratefully acknowledged. This study was partly supported by Deutsche Forschungsgemeinschaft Grant Ha 1706/8 to W. Hagen (R.B.-S).

\section{LITERATURE CITED}

Atkinson A (1998) Life cycle strategies of epipelagic copepods in the Southern Ocean. J Mar Syst 15:289-311

Båmstedt U (1986) Chemical composition and energy content. In: Corner EDS, O'Hara SCM (eds) The biological chemistry of marine copepods. Oxford University Press, Oxford, p 1-58

Beckmann W (1988) Seasonal patterns of mesopelagic calanoid copepods in the central Red Sea. Rapp Comm Int Mer Médit 31:300

Björnberg TKS (1972) Developmental stages of some tropical and subtropical planktonic marine copepods. Stud Fauna Curaçao Other Caribb Is 136:1-185

Böttger R (1987) The vertical distribution of micro- and small mesozooplankton in the central Red Sea. Biol Oceanogr 4:383-402

Böttger-Schnack R (1990a) Community structure and vertical distribution of cyclopoid copepods in the Red Sea. I. Central Red Sea, autumn 1980. Mar Biol 106:473-485

Böttger-Schnack R (1990b) Community structure and vertical distribution of cyclopoid copepods in the Red Sea. II. Aspects of regional and seasonal differences. Mar Biol 106:487-501

Böttger-Schnack R (1994) The microcopepod fauna in the Eastern Mediterranean and Arabian Seas: a comparison with the Red Sea fauna. Hydrobiologia 292/293:271-282

Böttger-Schnack R (1995) Summer distribution of micro- and small mesozooplankton in the Red Sea and Gulf of Aden, with special reference to non-calanoid copepods. Mar Ecol Prog Ser 118:81-102

Böttger-Schnack R (1999) Taxonomy of Oncaeidae (Copepoda, Poecilostomatoida) from the Red Sea. I. 11 species of Triconia gen. nov., and a redescription of $T$. similis (Sars) from Norwegian waters. Mitt Hamb Zool Mus Inst 96:37-128

Böttger-Schnack R (2001) Taxonomy of Oncaeidae (Copepoda, Poecilostomatoida) from the Red Sea. II. Seven species of Oncaea s. str. Bull Nat Hist Mus Lond Zool 67: 25-84

Böttger-Schnack R (2002) Taxonomy of Oncaeidae (Copepoda, Poecilostomatoida) from the Red Sea. VI. Morphology and zoogeography of Oncaea bispinosa sp. nov., a sister taxon of O. zernovi Shmeleva. J Plankton Res 24: 1107-1129

Böttger-Schnack R (2003) Taxonomy of Oncaeidae (Copepoda, Poecilostomatoida) from the Red Sea. V. Three species of Spinoncaea gen. nov. (ivlevi-group), with notes on zoogeographical distribution. Zool J Linn Soc 137:187-226

Böttger-Schnack R (2005) Taxonomy of Oncaeidae (Copepoda, Cyclopoida) from the Red Sea.VII. Oncaea cristata, a new species related to the ovalis-complex, and a revision of $O$. ovalis Shmeleva and $O$. bathyalis Shmeleva from the Mediterranean. Cah Biol Mar 46:161-209

Böttger-Schnack R, Huys R (2001) Taxonomy of Oncaeidae (Copepoda, Poecilostomatoida) from the Red Sea. III. Morphology and phylogenetic position of Oncaea subtilis Giesbrecht, 1892. Develop Hydrobiol (= Hydrobiologia) 453/454:467-481

Böttger-Schnack R, Schnack D, Weikert H (1989) Biological observations on small cyclopoid copepods in the Red Sea. J Plankton Res 11:1089-1101

Böttger-Schnack R, Hagen W, Schnack-Schiel SB (2001) The microcopepod fauna in the Gulf of Aqaba, northern Red Sea: species diversity and distribution of Oncaeidae (Poecilostomatoida). J Plankton Res 23:1029-1035

Boxshall GA (1977) The depth distributions and community 
organization of the planktonic cyclopoids (Crustacea: Copepoda) of the Cape Verde Islands region. J Mar Biol Assoc UK 57:543-568

Bunker AJ, Hirst AG (2004) Fecundity of marine planktonic copepods: global rates and patterns in relation to chlorophyll $a$, temperature and body weight. Mar Ecol Prog Ser 279:161-181

Checkley DM Jr (1980) The egg production of a marine planktonic copepod in relation to its food supply: laboratory studies. Limnol Oceanogr 25:430-446

Cornils A (2001) Räumliche Verbreitung von Phyto- und Zooplankton im nördlichen Roten Meer. Diploma Thesis, University of Bremen

Edmondson WT, Comita GW, Anderson GC (1962) Reproductive rate of copepods in nature and its relation to phytoplankton population. Ecology 43:625-634

Edwards FJ (1987) Climate and oceanography. In: Edwards AJ, Head SM (eds) Red Sea. Key environments. Pergamon, Oxford, p 45-69

Giesbrecht W (1892) Systematik und Faunistik der pelagischen Copepoden des Golfes von Neapel und der angrenzenden Meeres-Abschnitte. Fauna Flora Golf Neapel XIX:1-831

Green EP, Dagg MJ (1997) Mesozooplankton associations with medium to large marine snow aggregates in the northern Gulf of Mexico. J Plankton Res 19:435-447

Grossart HP, Simon M (2002) Bakterioplankton dynamics in the Gulf of Aqaba and in the northern Red Sea in early spring. Mar Ecol Prog Ser 239:263-276

Häse C, Stambler N, Al-Qutob M, Beese B, Dray M (2000) Primary production and its control by the light and nutrient regimes: a comparative study between the Gulf of Aqaba and the northern Red Sea. In: Pätzold J, Halbach PE, Hempel G, Weikert H (eds) Östliches MittelmeerNördliches Rotes Meer 1999, Cruise No 44, 22 January-16 May 1999. METEOR-Berichte 00-3, Universität Hamburg, 63-69

Heron GA (1977) Twenty-six species of Oncaeidae (Copepoda: Cyclopoida) from the Southwest Pacific-Antarctic area. In: Pawson DL (ed) Biology of the Antarctic Seas. VI. Antarct Res Ser 26:37-96

Heron GA, Bradford-Grieve JM (1995) The marine fauna of New Zealand: pelagic Copepoda: Poecilostomatoida: Oncaeidae. NZ Oceanogr Inst Mem 104:1-57

Heron GA, Frost BW (2000) Copepods of the family Oncaeidae (Crustacea: Poecilostomatoida) in the northeast Pacific Ocean and inland coastal waters of Washington State. Proc Biol Soc Wash 113:1015-1063

Hirakawa K (1995) Effects of temperature on egg production of a warm-water copepod Oncaea venusta Philippi (Poecilostomatoida). Bull Jpn Sea Natl Fish Res Inst 45:39-45

Hirst AG, Kiørboe T (2002) Mortality of marine planktonic copepods: global rates and patterns. Mar Ecol Prog Ser 230:195-209

Ho JS (1984) Copepoda associated with sponges, cnidarians, and tunicates of the Sea of Japan. Rep Sado Mar Biol Stn Niigata Univ 14:23-61

Hopcroft RR, Roff JC (1996) Zooplankton growth rates: diel egg production in the copepods Oithona, Euterpina and Corycaeus from tropical waters. J Plankton Res 18: 789-803

Hopcroft RR, Roff JC (1998) Zooplankton growth rates: the influence of female size and resources on egg production of tropical marine copepods. Mar Biol 132:79-86

Hopcroft RR, Roff JC, Chavez FP (2001) Size paradigms in copepod communities: a re-examination. Hydrobiologia 453/454:133-141
Hopkins TL (1985) The zooplankton community of Croker Passage, Antarctic Peninsula. Polar Biol 4:161-170

Huntley ME, Lopez MDG (1992) Temperature-dependent production of marine copepods: a global synthesis. Am Nat 140:201-242

Judkins DC (1980) Vertical distribution of zooplankton in relation to the oxygen minimum off Peru. Deep-Sea Res 27A:475-487

Kimor B, Golandsky B (1977) Microplankton of the Gulf of Elat: aspects of seasonal and bathymetric distribution. Mar Biol 42:55-67

Kiørboe T, Sabatini M (1994) Reproductive and life cycle strategies in egg-carrying cyclopoid and free-spawning calanoid copepods. J Plankton Res 16:1353-1366

Kiørboe T, Sabatini M (1995) Scaling of fecundity, growth and development in marine planktonic copepods. Mar Ecol Prog Ser 120:285-298

Kiørboe T, Møhlenberg F, Riisgård HU (1985) In situ feeding rates of planktonic copepods: a comparison of four methods. J Exp Mar Biol Ecol 88:67-81

Kovalev AV (1970) Size of the spawn in female Oncaea (Crustacea, Copepoda) from the Mediterranean Sea. Hydrobiol Zh 6:80-82 [English translation of: Kovalev AV (1970) Size of ovipositions in females of Oncaea (Crustacea, Copepoda) from the Mediterranean Sea. Gidrobiol Zh 6:91-94 (in Russian)]

Kršinić F (1998) Vertical distribution of protozoan and microcopepod communities in the South Adriatic Pit. J Plankton Res 20:1033-1060

Lindell D, Post AF (1995) Ultraphytoplankton succession is triggered by deep winter mixing in the Gulf of Aqaba (Eilat), Red Sea. Limnol Oceanogr 40:1130-1141

Mazzocchi MG, Paffenhöfer GA (1998) First observations on the biology of Clausocalanus furcatus (Copepoda, Calanoida). J Plankton Res 20:331-342

McKinnon AD (1996) Growth and development in the subtropical copepod Acrocalanus gibber. Limnol Oceanogr 41:1438-1447

McKinnon AD, Ayukai T (1996) Copepod egg production and food resources in Exmouth Gulf, Western Australia. Mar Freshw Res 47:595-603

McKinnon AD, Duggan S (2001) Summer egg production rates of paracalanid copepods in subtropical waters adjacent to Australia's North West Cape. Hydrobiologia 453/454:121-132

McKinnon AD, Thorrold SR (1993) Zooplankton community structure and copepod egg production in coastal waters of the central Great Barrier Reef. J Plankton Res 15: $1387-1411$

McLaren IA (1965) Some relationship between temperature and egg size, body size, developmental rate, and fecundity of the copepod Pseudocalanus. Limnol Oceanogr 10: $528-538$

Metz C (1996) Life strategies of dominant Antarctic Oithonidae (Cyclopoida, Copepoda) und Oncaeidae (Poecilostomatoida, Copepoda) in the Bellingshausen Sea. Ber Polarforsch/Rep Polar Res 207:1-123 (in German with English abstract)

Moore E, Sander F (1976) Quantitative and qualitative aspects of the zooplankton and breeding patterns of copepods at two Caribbean coral reef stations. Estuar Coast Mar Sci 4:589-607

Nielsen TG, Sabatini ME (1996) Role of cyclopoid copepods Oithona spp. in North Sea plankton communities. Mar Ecol Prog Ser 139:79-93

Nishibe Y, Ikeda T (2004) Vertical distribution, abundance and community structure of oncaeid copepods in the 
Oyashio region, western subarctic Pacific. Mar Biol 145: 931-941

Paffenhöfer GA (1983) Vertical zooplankton distribution on the northeastern Florida shelf and its relation to temperature and food abundance. J Plankton Res 5:15-33

Paffenhöfer GA (1993) On the ecology of marine cyclopoid copepods (Crustacea, Copepoda, Cyclopoida). J Plankton Res 15:37-55

Paffenhöfer GA, Mazzocchi MG (2003) Verical distribution of subtropical epiplanktonic copepods. J Plankton Res 25: $1139-1156$

Pätzold J, Halbach PE, Hempel G, Weikert H (2000) Östliches Mittelmeer - Nördliches Rotes Meer [Eastern Mediterranean - Northern Red Sea] 1999, Cruise No 44, 22 January-16 May 1999. METEOR-Berichte 00-3, Universität Hamburg

Poulin R (1995) Clutch size and egg size in free-living and parasitic copepods: a comparative analysis. Evolution 49: 325-336

Reiss Z, Hottinger L (1984) The Gulf of Aqaba ecological micropaleontology. Ecol Stud 50:1-354

Riccardi N, Mariotto L (2000) Seasonal variations in copepod body length: a comparison between different species in the Lagoon of Venice. Aquat Ecol 34:243-252

Richter C (1994) Regional and seasonal variability in the vertical distribution of mesozooplankton in the Greenland Sea. Ber Polarforsch 154:1-79+ appendix

Richter C (2000) Vertical distribution of chlorophyll a. In: Pätzold J, Halbach PE, Hempel G, Weikert H (eds) Östliches Mittelmeer-Nördliches Rotes Meer 1999, Cruise No 44, 22 January-16 May 1999. METEOR-Berichte 00-3, Universität Hamburg, p 62-63

Roman MR, Gauzens AL, Cowles TJ (1985) Temporal and spatial changes in epipelagic microzooplankton and mesozooplankton biomass in warm-core Gulf Stream ring 82-B. Deep-Sea Res 32:1007-1022

Sabatini ME, Kiørboe T (1994) Egg production, growth and development of the cyclopoid copepod Oithona similis. J Plankton Res 16:1329-1351

Satapoomin S (1999) Carbon content of some common

Editorial responsibility: Otto Kinne (Editor-in-Chief), Oldendorf/Luhe, Germany tropical Andaman Sea copepods. J Plankton Res 21: $2117-2123$

Satapoomin S, Nielsen TG, Hansen PJ (2004) Andaman Sea copepods: spatio-temporal variations in biomass and production, and role in the pelagic food web. Mar Ecol Prog Ser 274:99-122

Sazhina LI (1985) Fecundity and growth rate of copepods in different zones of equatorial countercurrent of the Indian Ocean. Pol Arch Hydrobiol 32:491-505

Steedman HF (1976) Examination, sorting and observation fluids. In: Steedman HF (ed) Zooplankton fixation and preservation. Monogr Oceanogr Methodol 4, UNESCO Press, Paris, p 182-183

Uye S (1981) Fecundity studies of neritic calanoid copepods Acartia clausi Giesbrecht and A steueri Smirnov: a simple empirical model of daily egg production. J Exp Mar Biol Ecol 50:255-271

Uye S, Sano K (1995) Seasonal reproductive biology of the small cyclopoid copepod Oithona davisae in a temperate eutrophic inlet. Mar Ecol Prog Ser 118:121-128

Uye S, Aoto I, Onbé T (2002) Seasonal population dynamics and production of Microsetella norvegica, a widely distributed but little-studied marine planktonic harpacticoid copepod. J Plankton Res 24:143-153

Webber MK, Roff JC (1995) Annual biomass and production of the oceanic copepod community off Discovery Bay, Jamaica. Mar Biol 123:481-495

Weikert H (1987) Plankton and the pelagic environment. In: Edwards AJ, Head SM (eds) Red Sea. Key environments. Pergamon, Oxford, p 90-111

Weikert H, John HC (1981) Experiences with a modified Bé multiple opening-closing plankton net. J Plankton Res 3: $167-176$

Wishner KF (1979) The biomass and ecology of the deep-sea benthopelagic (near-bottom) plankton. PhD dissertation, University of California-San Diego, CA

Yamaguchi A, Watanabe $Y$, Ishida $H$, Harimoto $T$ and 5 others (2002) Community and trophic structures of pelagic copepods down to greater depths in the western subarctic Pacific (WEST-COSMIC). Deep-Sea Res I 49:1007-1025

Submitted: September 22, 2004; Accepted: April 21, 2005 Proofs received from author(s): September 30, 2005 